\title{
Front Matter: Volume 7034
}

, "Front Matter: Volume 7034," Proc. SPIE 7034, Physical Chemistry of Interfaces and Nanomaterials VII, 703401 (29 September 2008); doi: $10.1117 / 12.806030$ SPIE. Event: NanoScience + Engineering, 2008, San Diego, California, United 


\title{
PROCEEDINGS OF SPIE
}

\section{Physical Chemistry of Interfaces and Nanomaterials VII}

\author{
Garry Rumbles \\ Oliver L. A. Monti \\ Editors
}

11-12 August 2008
San Diego, California

Sponsored and Published by

SPIE

Cosponsored by

NREL—National Renewable Energy Laboratory (USA)

Volume 7034 
The papers included in this volume were part of the technical conference cited on the cover and title page. Papers were selected and subject to review by the editors and conference program committee. Some conference presentations may not be available for publication. The papers published in these proceedings reflect the work and thoughts of the authors and are published herein as submitted. The publisher is not responsible for the validity of the information or for any outcomes resulting from reliance thereon.

Please use the following format to cite material from this book:

Author(s), "Title of Paper," in Physical Chemistry of Interfaces and Nanomaterials VII, edited by Garry Rumbles, Oliver L. A. Monti, Proceedings of SPIE Vol. 7034 (SPIE, Bellingham, WA, 2008) Article CID Number.

ISSN 0277-786X

ISBN 9780819472540

Published by

SPIE

P.O. Box 10, Bellingham, Washington 98227-0010 USA

Telephone +1 3606763290 (Pacific Time) · Fax +1 3606471445

SPIE.org

Copyright (c) 2008, Society of Photo-Optical Instrumentation Engineers

Copying of material in this book for internal or personal use, or for the internal or personal use of specific clients, beyond the fair use provisions granted by the U.S. Copyright Law is authorized by SPIE subject to payment of copying fees. The Transactional Reporting Service base fee for this volume is $\$ 18.00$ per article (or portion thereof), which should be paid directly to the Copyright Clearance Center (CCC), 222 Rosewood Drive, Danvers, MA 01923. Payment may also be made electronically through CCC Online at copyright.com. Other copying for republication, resale, advertising or promotion, or any form of systematic or multiple reproduction of any material in this book is prohibited except with permission in writing from the publisher. The CCC fee code is 0277-786X/08/\$18.00.

Printed in the United States of America.

Publication of record for individual papers is online in the SPIE Digital Library.

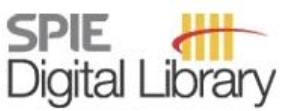

SPIEDigitalLibrary.org

Paper Numbering: Proceedings of SPIE follow an e-First publication model, with papers published first online and then in print and on CD-ROM. Papers are published as they are submitted and meet publication criteria. A unique, consistent, permanent citation identifier (CID) number is assigned to each article at the time of the first publication. Utilization of CIDs allows articles to be fully citable as soon they are published online, and connects the same identifier to all online, print, and electronic versions of the publication. SPIE uses a six-digit CID article numbering system in which:

- The first four digits correspond to the SPIE volume number.

- The last two digits indicate publication order within the volume using a Base 36 numbering system employing both numerals and letters. These two-number sets start with $00,01,02,03,04,05$, 06, 07, 08, 09, OA, OB ... 0Z, followed by 10-1Z, 20-2Z, etc.

The CID number appears on each page of the manuscript. The complete citation is used on the first page, and an abbreviated version on subsequent pages. Numbers in the index correspond to the last two digits of the six-digit CID number. 


\section{Contents}

$\checkmark$ Conference Committee

vii Revivals of molecular nonlinear optics in physics, chemistry, and life sciences (Plenary Paper) [7040-100]

J. Zyss, Lab. de Photonique Quantique et Moléculaire, CNRS, Institut d'Alembert (France)

\section{SESSION 1 CONJUGATED POLYMER INTERFACES}

703402 Critical interfaces in new solar cell materials: organic heterojunctions and heterojunctions involving semiconductor nanoparticles (Invited Paper) [7034-01]

N. R. Armstrong, D. Alloway, A. Graham, C. Shallcross, M. Brumbach, P. A. Veneman,

D. Placencia, W. Wang, The Univ. of Arizona (United States)

703403 The electron and energy transfer between oligothiophenes and thieno[3,4-b]thiophene units [7034-02]

J. Szarko, Northwestern Univ. (United States) and Argonne National Lab. (United States);

J. Guo, Argonne National Lab. (United States) and The Univ. of Chicago (United States);

Y. Liang, The Univ. of Chicago (United States); B. Rolczynski, Northwestern Univ. (United

States) and Argonne National Lab. (United States); L. Yu, The Univ. of Chicago (United

States); L. X. Chen, Northwestern Univ. (United States) and Argonne National Lab. (United

States)

703404 Interfacial charge separation and trapping in a photovoltaic polymer blend observed with ultrafast vibrational spectroscopy [7034-03]

R. D. Pensack, K. M. Banyas, L. W. Barbour, J. B. Asbury, The Pennsylvania State Univ. (United States)

\section{SESSION 2 PHOTOPHYSICS AT SEMI-CONDUCTOR INTERFACES}

703408 London force and energy transportation between interfacial surfaces [7034-07]

D. S. Bradshaw, J. M. Leeder, J. Rodríguez, D. L. Andrews, Univ. of East Anglia (United Kingdom)

703409 Toward single molecule interfacial charge transfer dynamics in a dye-sensitized solar cell model [7034-08]

L. K. Schirra, M. L. Blumenfeld, B. S. Tackett, J. M. Tyler, O. L. A. Monti, The Univ. of Arizona (United States)

7034 OC Characterization of siloxane adsorbates covalently attached to $\mathrm{TiO}_{2}$ [7034-1 1]

N. Iguchi, C. Cady, R. C. Snoeberger III, B. M. Hunter, E. M. Sproviero, C. A. Schmuttenmaer, R. H. Crabtree, G. W. Brudvig, V. S. Batista, Yale Univ. (United States) 


\section{SESSION 3 QUANTUM-CONFINED NANOSCALE STRUCTURES}

$7034 \mathrm{OH} \quad$ Novel inorganic nanomaterials generated with highly concentrated sunlight [7034-16] J. M. Gordon, E. A. Katz, D. Feuermann, Ben-Gurion Univ. of the Negev (Israel);

A. Albu-Yaron, M. Levy, R. Tenne, Weizmann Institute of Science (Israel)

POSTER SESSION

$70340 Q \quad$ Negative magnetoresistance due to weak localization and electron-electron interactions effects in metallic $\mathrm{n}$-type InP semiconductor at very low temperatures with magnetic field [7034-25]

A. El kaaouachi, R. Abdia, A. Nafidi, Univ. Ibn Zohr (Morocco); G. Biskupski, Lab. de Spectroscopie Hertzienne, CNRS, Univ. des Sciences et Technique de Lille I (France); J. Hemine, Univ. of Science and Technology of Mohammadia (Morocco)

7034 OS Electronic structure of the $\mathrm{AgCl}$ nanosystems with atomically rough surfaces, edge dislocations, and isoelectronic substitutional impurities [7034-27]

Y. K. Timoshenko, V. A. Shunina, Voronezh State Univ. (Russia)

Author Index 


\title{
Conference Committee
}

\author{
Symposium Chairs
}

David L. Andrews, University of East Anglia Norwich (United Kingdom) James G. Grote, Air Force Research Laboratory (United States)

Kevin J. Liddane, Oerlikon Optics USA, Inc. (United States)

Conference Chairs

Garry Rumbles, National Renewable Energy Laboratory (United States)

Oliver L. A. Monti, The University of Arizona (United States)

Conference Cochairs

Oleg V. Prezhdo, University of Washington (United States)

Sergei Tretiak, Los Alamos National Laboratory (United States)

Session Chairs

1 Conjugated Polymer Interfaces

Garry Rumbles, National Renewable Energy Laboratory (United States)

2 Photophysics at Semi-conductor Interfaces

Sergei Tretiak, Los Alamos National Laboratory (United States)

3 Quantum-Confined Nanoscale Structures

Oleg V. Prezhdo, University of Washington (United States)

$4 \quad$ Single-species Spectroscopy

Oliver L. A. Monti, The University of Arizona (United States) 